Terbit online pada laman web jurnal: http://jurnal.iaii.or.id

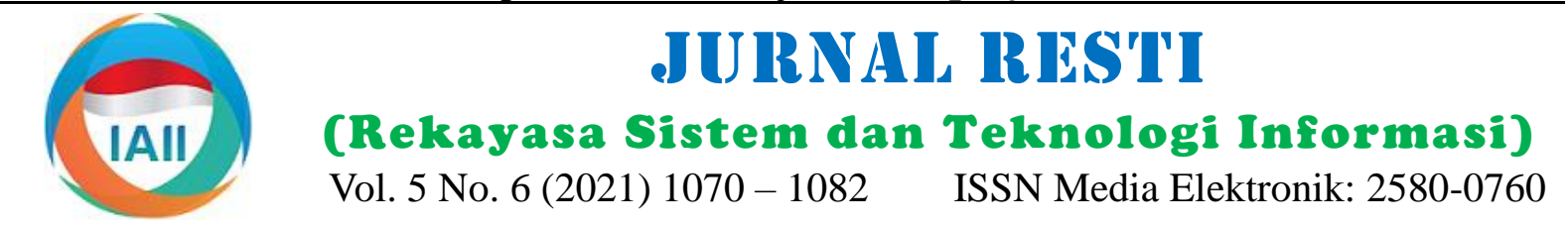

\title{
Deteksi Kesamaan Teks Jawaban pada Sistem Test Essay Online dengan Pendekatan Neural Network
}

\author{
I Made Suwija Putra ${ }^{1}$, Putu Jhonarendra ${ }^{2}$, Ni Kadek Dwi Rusjayanthi ${ }^{3}$ \\ ${ }^{1,3}$ Program Studi Teknologi Informasi, Fakultas Teknik, Universitas Udayana \\ ${ }^{2}$ Programmer PT Laksita Emi Saguna \\ ${ }^{1}$ putrasuwija@unud.ac.id, ${ }^{2}$ jhonarendra@ gmail.com, ${ }^{3}$ dwi.rusjayanthi@unud.ac.id
}

\begin{abstract}
E-learning is an online learning system that applies information technology in the teaching process. E-learning used to facilitate information delivery, learning materials and online test or assignments. The online test in evaluating students' abilities can be multiple choice or essay. Online test with essay answers is considered the most appropriate method for assessing the results of complex learning activities. However, there are some challenges in evaluating students essay answers. One of the challenges is how to make sure the answers given by students are not the same as other students answers or 'copypaste'. This study makes a similarity detection system (Similarity Checking) for students' essay answers that are automatically embedded in the e-learning system to prevent plagiarism between students. In this paper, we use Artificial Neural Network $(A N N)$, Latent Semantic Index (LSI), and Jaccard methods to calculate the percentage of similarity between students' essays. The essay text is converted into array that represents the frequency of words that have been preprocessed data. In this study, we evaluate the result with mean absolute percentage error (MAPE) approach, where the Jaccard method is the actual value. The experimental results show that the ANN method in detecting text similarity has closer performance to the Jaccard method than the LSI method and this shows that the ANN method has the potential to be developed in further research.
\end{abstract}

Keywords: Similarity Checker, Neural Network, LSI, Jaccard

\begin{abstract}
Abstrak
E-learning adalah sistem pembelajaran daring yang menerapkan teknologi informasi dalam proses belajar mengajar. Fungsi elearning adalah untuk mempermudah penyampaian informasi, memberi materi pembelajaran dan mengerjakan soal atau tugas. Penerapan kuis ujian dalam evaluasi kemampuan siswa dapat berupa pilihan ganda atau jawaban essay. Tugas dengan kuis essay dianggap sebagai metode yang paling tepat untuk menilai hasil kegiatan belajar yang kompleks. Namun, ada beberapa tantangan dalam mengevaluasi jawaban essay siswa. Salah satu tantangannya adalah bagaimana memastikan jawaban yang diberikan siswa tidak sama dengan jawaban siswa lain atau 'copy-paste' jawaban siswa lain. Penelitian ini membuat sebuah sistem pendeteksi kesamaan (Similarity Checking) untuk jawaban essay siswa secara otomatis tertanam dalam sistem e-learning untuk membantu mencegah plagiarisme antar sesama siswa dalam tugas yang dikerjakan. Dalam paper ini, kami menggunakan metode Artificial Neural Network (ANN), Latent Semantic Index (LSI), dan Jaccard untuk menghitung persentase kesamaan antar essay siswa. Teks essay diubah menjadi array yang mewakili frekuensi kata yang sebelumnya sudah dilakukan preprocessing data. Dalam penelitian ini, kami menggunakan hasil evaluasi dengan pendekatan mean absolute percentage error (MAPE), dimana metode Jaccard sebagai nilai aktualnya. Hasil percobaan menunjukkan bahwa metode ANN dalam pendeteksian kesamaan teks memiliki kinerja yang lebih mendekati metode Jaccard dibandingkan dengan metode LSI dan hal ini menunjukkan kedepannya metode ANN berpotensi untuk dikembangkan pada penelitian lebih lanjut.
\end{abstract}

Kata kunci: Deteksi Similarity, Neural Network, LSI, Jaccard

\section{Pendahuluan}

Perkembangan pesat teknologi mempengaruhi semua bidang kehidupan manusia. Teknologi membantu kehidupan manusia dalam menyelesaikan pekerjaan dengan cepat, efisien dan menekan human error.
Teknologi dalam perkembangan juga dapat dirasakan pada lingkup pendidikan yakni salah satunya teknologi informasi. Teknologi informasi pada dunia pendidikan dapat mengubah bentuk aktivitas yang selama ini secara tatap muka menjadi bisa secara jarak jauh [1]. Masa

Diterima Redaksi: 06-10-2021 | Selesai Revisi: 03-12-2021 | Diterbitkan Online: 30-12-2021 
pandemi Covid 19 secara tidak langsung membuat Deteksi kesamaan adalah teknik untuk mencari, pemanfaatan teknologi informasi menjadi peran yang menghitung, dan menemukan kesamaan dari dua atau sangat penting guna mewujudkan aktivitas pembelajaran lebih objek dengan output berupa persentase (0-100\%). jarak jauh yang baik [2]. Salah satu teknologi informasi Deteksi kesamaan pada $I R$ secara teknis memiliki pembelajaran jarak jauh adalah dengan menggunakan beberapa langkah sebelum masuk ke metode utama. sistem e-learning. Saat ini setiap elemen di bidang Tahap pertama adalah pengumpulan data atau akuisisi pendidikan telah menerapkan e-learning dalam proses data. Tahap kedua adalah tahap preprocessing dan tahap pembelajarannya dan ini diproyeksikan akan terus yang terakhir adalah proses perhitungan tingkat digunakan pasca pandemic dengan konsep hybrid yang kesamaan text dalam bentuk persentase.

memadukan dengan pembelajarantatap muka.

Beberapa peneliti telah meneliti teknik pendeteksian E-learning ke depannya memiliki tantangan untuk kesamaan teks. Salah satu penelitian tentang deteksi melengkapi fitur-fitur yang efektif dalam menyajikan kesamaan teks adalah artikel berjudul Context similarity dan menawarkan informasi yang akurat serta spesifik measure using fuzzy formal concept analysis [7]. kepada pengguna, seperti batasan sistem, profil Penelitian ini mengusulkan metode empiris untuk pengguna, fakta dan opini pengetahuan web pengguna, memperkirakan kesamaan semantik menggunakan komunikatif dan kemampuan multitasking dalam satu Analisis Konsep Formal Fuzzy. Pengelompokan pola arsitektur agar manfaat dasar dengan adanya teknologi leksikal yang berbeda memungkinkan untuk mewakili informasi itu bisa benar-benar dirasakan [3][4]. Salah hubungan semantik antara dua kata secara akurat.

satu contoh fitur e-learning adalah manajemen materi pembelajaran yang dunggah oleh pengajar secara terstruktur sehingga bisa diakses oleh siswa dan terdokumentasi dengan baik. Fitur lainnya yang tidak kalah penting adalah proses evaluasi pembelajaran siswa, di sini pengajar mengatur waktu ujian, jenis ujian, membuat soal-soal ujian dan memberikan penilaian terhadap hasil ujian siswa.

Khusus untuk jenis ujian dapat berupa pilihan ganda ataupun essay. Umumnya, penggunaan pilihan ganda lebih banyak diterapkan pada ujian online karena lebih sederhana praktis dalam evaluasi jawaban siswa, karena sistem secara otomatis mencocokkan dengan kunci jawaban yang ada dan nilai bisa didapatkan secara cepat. Sedangkan pertanyaan essay dalam proses evaluasi jawaban harus mempertimbangkan beberapa faktor, salah satunya dalam evaluasi jawaban essay mengharuskan untuk membaca secara saksama jawaban essay berupa kalimat-kalimat karangan untuk dapat mengerti informasi yang tersampaikan pada jawaban siswa tersebut, sehingga bisa ditentukan apakah jawaban tersebut bernilai benar atau salah [5]. Selain itu proses pemberian nilai jawaban essay juga perlu menentukan kesamaan teks adala mempertimbangkan kesamaan isi jawaban essay antar Winnowing. Algoritma winnowing adalah metode yang siswa. Hal ini untuk melihat tingkat kejujuran siswa digunakan untuk mendeteksi common subsequence sehingga bisa sebagai bahan pertimbangan dalam dalam membandingkan dua teks atau lebih. memberikan nilai. Tugas deteksi tingkat kesamaan jawaban antar siswa gambaran bahwa teknik pendeteksian kesamaan teks secara teknologi bisa dimasukkan sebagai fitur dalam e- telah banyak dilakukan dengan berbagai macam metode learning dengan menggunakan teknologi Natural mulai dari metode algoritma matematis seperti Ratcliff, Language Processing (NLP) pada sub bidang ilmu Jaccard, Cosine Similarity, Winnowing dan LSI, sampai Information Retrieval (IR) yaitu tugas pengambilan dengan saat ini menggunakan metode pendekatan informasi terkait dengan representasi, penyimpanan, learning-based (machine learning dan neural network). akses peran ke informasi [6], sehingga pengajar Deteksi kesamaan teks menggunakan neural network dimudahkan dalam melihat tingkat kesamaan jawaban memang mulai telah banyak dikerjakan namun khusus essay antar siswa
State of the art penelitian sebelumnya memberikan

Studi lain yang berjudul Learning Text Similarity with Siamese Recurrent Networks [8] memperkenalkan konsep pembelajaran mendalam untuk mempelajari metrik kesamaan dalam variabel panjang urutan dengan arsitektur Siamese.

Penelitian lain tentang metode kesamaan teks adalah Rancang Bangun Aplikasi Deteksi Kesamaan Dokumen Teks Menggunakan Algoritma Ratcliff/Obershelp [9]. Penelitian ini menggunakan algoritma Ratcliff/Obershelp untuk menilai seberapa mirip pola pengujian dilakukan pada 12 dokumen dengan tingkat
penajian algoritma, kesamaan dan posisi yang bervariasi. Nilai yang diperoleh mendekati nilai prediksi, dan nilai pada dokumen yang memiliki kesamaan yang sama tetap
bagian yang berbeda mendapatkan nilai yang berbeda.

Deteksi Plagiarisme Tingkat Kesamaan Judul Skripsi Algoritma Winnowing [10] mengimplementasikan suatu algoritma untuk untuk neural network dengan arsitektur AND Operator belum pernah diteliti secara langsung untuk kasus text

DOI: https://doi.org/10.29207/resti.v5i6.3544

Lisensi: Creative Commons Attribution 4.0 International (CC BY 4.0) 
jawaban ujian essay siswa pada sistem e-learning. Oleh Proses ini dilakukan oleh pengajar dengan memberi nilai karena itu pada penelitian ini dibuat sebuah sistem jawaban siswa berdasarkan tingkat kesetaraan jawaban pendeteksian kesamaan jawaban siswa menggunakan siswa yang dihitung dengan menggunakan perbandingan metode utama yaitu neural network (NN) dengan tiga metode yaitu ANN, LSI, dan Jaccard. pengembangan pengujian pada fungsi aktivasi dan penggunaan multi hidden layer. Sedangkan untuk melakukan evaluasi metode ANN, dalam penelitian ini menggunakan metode pembanding lainnya, yaitu LSI dan Jaccard Similarity. Metode LSI ini digunakan dalam penelitian ini dengan alasan masih sedikit penelitian menggunakan metode LSI dalam mendeteksi kesamaan teks, sedangkan untuk penggunaan metode Jaccard Similarity lebih sebagai metode acuan hasil nilai tingkat kesamaan sebuah jawaban sehingga bisa mengukur kinerja antara metode ANN dengan LSI menggunakan pendekatan evaluasi MAPE. Hal ini dengan pertimbangan metode Jaccard Similarity terbilang metode yang sederhana tetapi cukup akurat untuk mendeteksi kesamaan teks secara lexical [11].

Adapun secara struktur yang dibahas pada paper ini adalah sebagai sebagai berikut: Bagian 2 metode yang digunakan dalam penelitian; Bagian 3 menyajikan hasil eksperiment yang didapat dan menganalisanya; Bagian 4 menguraikan kesimpulan yang didapat.

\section{Metode Penelitian}

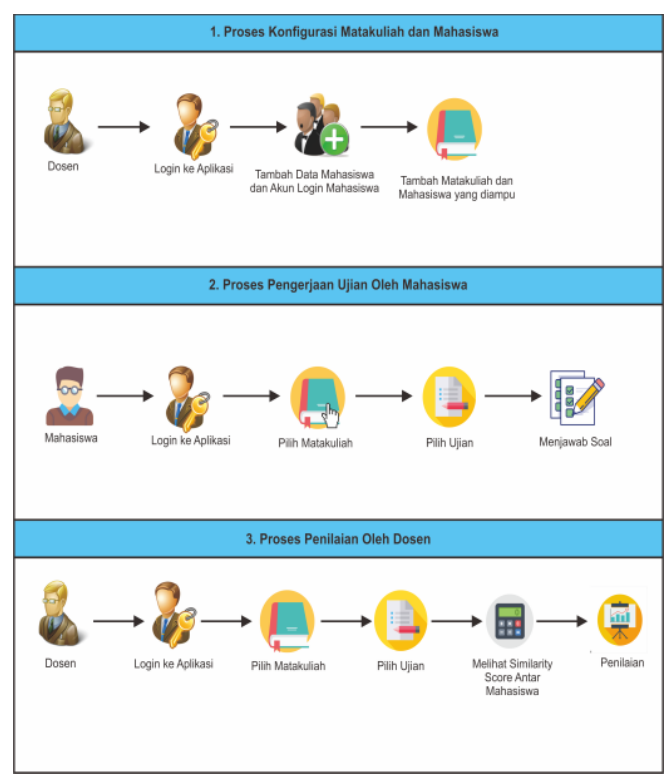

Gambar 1 Alur sistem deteksi kesamaan jawaban pada aplikasi $e$ learning

Dalam penelitian ini, menggunakan metode ANN yang Bagian ini menjelaskan mengenai langkah-langkah dikerjakan melalui empat tahap yaitu akuisisi data, proses penerapan teknologi kesamaan teks dengan preprocessing, dan pengukuran kesamaan teks. Akuisisi metode artificial neural network (ANN) yang data adalah tahap pengambilan data, preprocessing ditanamkan pada prototype sistem e-learning pada adalah tahap pembersihan data, processing atau penelitian ini. Tujuan penelitian ini adalah menguji kalkulasi adalah proses inti dalam memberikan fungsionalitas dan kinerja dari metode ANN dalam keputusan tentang tingkat persentase kesamaan antar menghasilkan persentase kesamaan dengan teks.

membandingkannya dengan metode lain yaitu Latent Semantic Indexing (LSI) yang dimana nilai persentase tingkat similarity metode Jaccard sebagai nilai acuan.

Gambar 1 adalah gambaran alur prototype sistem $e$ learning dalam proses menguji metode ANN dalam mengeluarkan hasil presentase kesamaan jawaban essay antar siswa. Terdapat 3 proses berbeda. Proses pertama adalah mengkonfigurasi mata pelajaran dan siswa, atau proses inisialisasi penggunaan aplikasi dimulai dengan pengajar membuat mata pelajaran. Pengajar mendaftarkan siswa ke mata pelajaran tersebut. Dalam setiap mata pelajaran, pengajar dapat membuat sesi tes online dan pertanyaan yang akan dijawab oleh siswa.

Proses kedua adalah pengerjaan ujian oleh siswa. Siswa yang mengikuti ujian memulai dengan login ke sistem, dimana aplikasi akan menampilkan halaman dashboard siswa. Seorang siswa memilih mata pelajaran dan sesi tes online. Kemudian, siswa menjawab setiap pertanyaan yang diberikan secara langsung dalam sistem.

Tahap terakhir adalah proses penilaian oleh pengajar.

\subsection{Pengolahan Data}

Pada penelitian ini pengolahan data dilakukan untuk menyiapkan data input yaitu data teks agar bisa dibaca oleh metode deteksi kesamaan text (ANN, LSI, dan Jaccard) untuk diterjemahkan hasilnya berupa presentase tingkat kesamaan. Proses dilakukan secara bertahap hingga berhasil mengubah data text menjadi deretan nilai numerik berupa array. Adapun tahapan pengolahan data adalah sebagai berikut

\subsubsection{Akuisisi Data}

Penelitian ini menyiapkan data input yang bersumber dari jawaban essay siswa pada sebuah sistem e-learning yang sudah berjalan di suatu universitas. Proses akuisisi data dikerjakan dengan menyalin dan menginput data secara manual ke dalam database sistem tes online yang dibangun pada penelitian ini. Metode input manual dipilih dengan pertimbangan agar pada saat proses pengujian metode pada penelitian ini tidak mengganggu jalannya sistem e-learning universitas yang sedang beroperasi.

DOI: https://doi.org/10.29207/resti.v5i6.3544

Lisensi: Creative Commons Attribution 4.0 International (CC BY 4.0) 
Data jawaban essay siswa disimpan dalam database Preprocessing dapat mempengaruhi kinerja metode MySQL dalam format raw text atau teks mentah ANN, LSI, dan Jaccard saat mendeteksi kesamaan teks. sehingga tidak memerlukan konversi dokumen saat Proses preprocessing juga sama dilakukan pada text mengekstrak teks. Contoh data raw text jawaban siswa corpus jawaban siswa yang akan diperbandingkan. dapat dilihat pada Tabel 1.

Berikut ini detail tahapan dari preprocessing.

\begin{tabular}{|c|c|}
\hline Nama & Text corpus \\
\hline $\begin{array}{l}\text { Septiana } \\
\text { Eka } \\
\text { Arwanda } \\
\text { Riski }\end{array}$ & $\begin{array}{l}\text { Peran Pihak Internal yaitu untuk menjalankan } \\
\text { perusahaan dengan memanfaatkan sumber } \\
\text { daya yang ada secara efektif. } \\
\text { Peran Pihak Eksternal yaitu untuk mendukung } \\
\text { keberlangsungan usaha. }\end{array}$ \\
\hline $\begin{array}{l}\text { I Gusti } \\
\text { Agung } \\
\text { Surya } \\
\text { Pramana w }\end{array}$ & $\begin{array}{l}\text { ligkungan internal bekerja dengan baik dalam } \\
\text { lingkungan bisnis dalam lingkungan tersebut } \\
\text { external bekerja di lingkungan tidak resmi } \\
\text { yang bertugas dalam memximalkan bisnis }\end{array}$ \\
\hline $\begin{array}{l}\text { Agung } \\
\text { Adhika } \\
\text { Mas } \\
\text { Pratama }\end{array}$ & $\begin{array}{l}\text { Lingkungan Internal -> Tenaga kerja,modal } \\
\text { dan peralatan. Peran dari lingkungan Internal } \\
\text { ini untuk menentukan kekuatan perusahaan } \\
\text { dan juga mengetahui kelemahan perusahaan. } \\
\text { Lingkungan Eksternal -> Konsumen,Pesaing, } \\
\text { Ekonomi. Peran dari lingkungan Eksternal ini } \\
\text { untuk menentukan peluang pasar dan juga } \\
\text { ancaman dari luar/pesaing }\end{array}$ \\
\hline $\begin{array}{l}\text { Made Satya } \\
\text { Wibawa } \\
\text { Esa } \\
\text { Narendra }\end{array}$ & $\begin{array}{l}\text { Lingkungan Internal (Dalam) contohnya } \\
\text { karyawan, manager, CEO dan lain-lain yang } \\
\text { memiliki peran langsung (direct) untuk } \\
\text { memperngaruhi nasib perusahaan } \\
\text { Lingkungan Eksternal (Luar) contohnya } \\
\text { Konsumen, pesaing, pemasok dan lain-lain } \\
\text { yang memiliki peran bahwa kekuatan } \\
\text { lingkungan luar tersebut memiliki potensi } \\
\text { mempengaruhi kinerja atau keberlangsungan } \\
\text { perusahaan. }\end{array}$ \\
\hline
\end{tabular}

Tabel 1 merupakan contoh raw text dari 5 siswa pada satu soal. Secara keseluruhan, data essay diambil dari 2 sesi ujian dari 2 matakuliah yang berbeda. Dengan total terdapat 290 essay dengan ukuran $398 \mathrm{~KB}$ di dalam database.

Raw text berguna untuk tahap pemrosesan teks karena jenis data ini tidak memiliki format yang tidak diperlukan dalam analisis teks, seperti format teks cetak tebal, ukuran font, dan warna teks.

\subsubsection{Preprocessing}

Tahap preprocessing dilakukan sebelum sistem mengeksekusi proses utama. Tahap preprocessing dalam penelitian ini menggunakan data teks corpus jawaban siswa yang yang sebelumnya tersimpan di database sistem tes online. Alasan utama dari tahap preprocessing adalah sebagai proses membersihkan data agar data lebih sempurna untuk diolah pada proses utama dengan sedikit noise. Alur tahapan preprocessing seperti terlihat pada Error! Reference source not found.

Tahap akhir dari preprocessing akan membentuk TF (Term Frequency) dengan tipe data array dari kata-kata dasar yang ada di dalam inputan corpus jawaban essay siswa agar bisa digunakan sebagai nilai input untuk algoritma similarity yang digunakan pada penelitian ini.

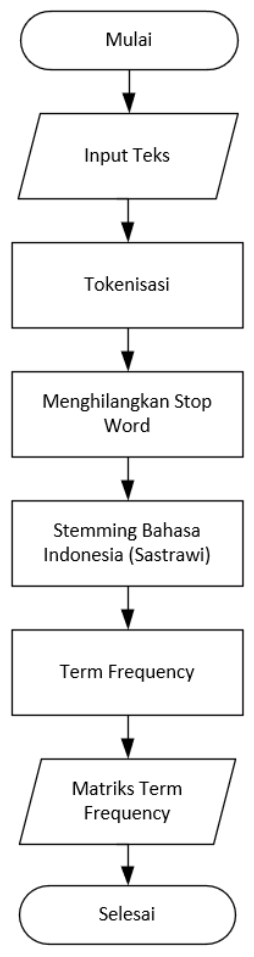

Gambar 2. Flow chart preprocessing

\subsubsection{Tokenisasi}

Langkah pertama dalam tahap preprocessing adalah tokenisasi, yaitu mengambil fitur kata, frasa, atau simbol terdapat dalam teks [12] yang dinamakan sebagai token. Metode deteksi kata atau word tokenization mengekstraksi kata dalam teks dengan cara sederhana yaitu menandai kelompok huruf yang dikelilingi dengan spasi untuk dipisahkan sebagai sebuah token [13].

Dalam pemrograman, token-token tersebut disajikan dalam bentuk array index. Pada penelitian ini karakter dan simbol khusus dihilangkan karena dalam mendeteksi kesamaan teks, hanya perlu menghitung kata-kata yang sama antara dua dokumen atau lebih.

\subsubsection{Stop word}

Hasil dari proses tokenisasi yang berupa kumpulan kata dalam array, diproses lebih lanjut dengan menghilangkan kata umum yang sering muncul (stop word), namun tidak perlu diperhitungkan untuk mendapatkan konteks utama dalam sebuah teks. Contoh yang stop word pada Bahasa Indonesia adalah 'yang', 'di', 'untuk', dan 'dari' [14].

Pada penelitian ini stop word diperlukan, karena jika kata-kata umum atau konjungsi yang sering muncul

DOI: https://doi.org/10.29207/resti.v5i6.3544

Lisensi: Creative Commons Attribution 4.0 International (CC BY 4.0) 
tidak dihilangkan, maka persentase kesamaan text akan cenderung tinggi sehingga mengganggu keakuratan metode similarity. Kata-kata umum yang sering muncul bisa disebut noise dalam text processing.

\subsubsection{Stemming}

Stemming adalah teknik pencarian kata dasar dari kata yang sudah berimbuhan. Dalam Bahasa Indonesia imbuhan ada berupa awalan, akhiran, konfiks, dan sisipan dalam kata [15].

Penelitian ini menggunakan proses stemming untuk bisa mendapatkan kata dasar dari token yang terkumpul pada setiap text jawaban siswa agar lebih tepat dicocokan secara sintaksis. Misalnya, text jawaban siswa 'A' memiliki kata 'memukul', sedangkan text jawaban siswa 'B' memiliki kata 'dipukul'. Setelah proses stemming, Corpus A dan B akan memiliki 'pukul' karena 'pukul' adalah kata dasar. Dengan demikian, sistem deteksi kesamaan teks akan mengatakan kedua dokumen sangat mirip, walaupun berbeda bentuk imbuhan kata. Pada stemming Bahasa Indonesia, teknik terkenal digunakan adalah Sastrawi. Sastrawi mampu mengurangi over stemming dan under stemming serta waktu pengerjaan lebih cepat dibandingkan library lain [16][17].

\subsubsection{Term Frequency}

Hasil dari kumpulan kata-kata dasar yang didapat dari proses stemming kemudian dihitung frekuensi kemunculannya dalam sebuah dokumen. Teknik ini disebut dengan istilah term frequency (TF). TF digunakan untuk mendapatkan data terkuantisasi untuk diproses lebih lanjut pada tahap perhitungan kesamaan teks.

TF juga merupakan metode untuk mengubah kata-kata yang telah diproses sebelumnya menjadi array. konversi kata menjadi nilai array dilakukan dengan menghitung jumlah kemunculan kata $(t)$ ke i dalam suatu corpus $(d)$ ke j seperti pada persamaan 1 dan mengubahnya menjadi angka sesuai dengan jumlah kemunculannya.

$W_{T F}\left(t_{i}, d_{j}\right)=f\left(t_{i}, d_{j}\right)$

Pada penelitian ini tahap TF menghasilkan dua nilai array yaitu nilai perbandingan jawaban essay siswa (text query) dan nilai frekuensi jawaban essay siswa pembanding (indexed object) yang digunakan sebagai input untuk metode Jaccard dan ANN.

Sedangkan untuk metode LSI, diperlukan proses lanjutan data input berupa frekuensi kata yang sudah terhitung bobot setiap kata untuk satu corpus atau yang lebih dikenal dengan Term Frequency - Inverse Document Frequency (TF-IDF). IDF langkah untuk kurangi bobot kata yang sering muncul di corpus dan tambah bobot kata yang jarang terjadi [18] dengan menggunakan persamaan 2 .

$W_{I D F}\left(t_{i}, d_{j}\right)=1+\log \left(\frac{D}{d\left(t_{i}\right)}\right)$

$W_{I D F}\left(t_{i}, d_{j}\right)$ adalah nilai IDF dari term ke i pada corpus ke $\mathrm{j}, \quad D$ adalah jumlah kesuluruhan corpus dan $d\left(t_{i}\right)$ adalah jumlah corpus yang mengandung term ke i. dari hasil IDF tersebut kemudian dilakukan perkalian dengan TF seperti pada persamaan 3.

$W_{T F-I D F}\left(t_{i}, d_{j}\right)=W_{T F}\left(t_{i}, d_{j}\right) * W_{I D F}\left(t_{i}, d_{j}\right)$

$W_{T F-I D F}\left(t_{i}, d_{j}\right)$ adalah nilai TF-IDF dari term ke i pada corpus ke j.

\title{
2.1.3 Perhitungan Kesamaan
}

Proses utama untuk menghitung kesamaan teks pada penelitian ini mengambil data masukan dari proses sebelumnya yaitu TF yang menghasilkan deretan 2 nilai frekuensi kata dalam format array. Kedua nilai array ini dimasukkan ke dalam ANN sebagai input data untuk mencari nilai prediktif kesamaan teks untuk kedua input tersebut.

Proses pendeteksian kesamaan teks ini juga membandingkan hasil dari metode LSI dan Jaccard, yang merupakan metode terkenal untuk teknik kesamaan teks. Perbandingan ini membandingkan persentase nilai kesamaan yang dihasilkan oleh metode ANN dan LSI dengan Jaccard sebagai nilai referensi untuk tingkat kesamaan yang baik.

\subsubsection{Artificial Neural Network (ANN)}

Metode Artificial Neural Network (ANN) merupakan metode utama yang diterapkan dalam penelitian untuk mengatasi permasalahan bagaimana mendeteksi kesamaan jawaban siswa pada sistem e-learning. Neuron pada ANN mencoba mereplikasi struktur dan perilaku neuron biologis manusia. Sebuah neuron terdiri dari input (dendrit) dan output (sinaps melalui akson). Setiap neuron memiliki fungsi yang menentukan aktivasi neuron [19]. Alur proses dari metode ANN dapat dilihat pada Gambar 3.

Alur proses metode ANN untuk menghitung kesamaan teks terbagi menjadi dua tahap. Dua tahap tersebut adalah pelatihan (training) dan pengujian (testing). Pada tahap pelatihan metode ANN dimulai dengan mengimport library dan menginisialisasi arsitektur Neural Network (NN). Penelitian ini menggunakan dua node pada input layer, satu hidden layer dengan empat node dan satu node pada output layer seperti terlihat pada

\author{
(1)
}




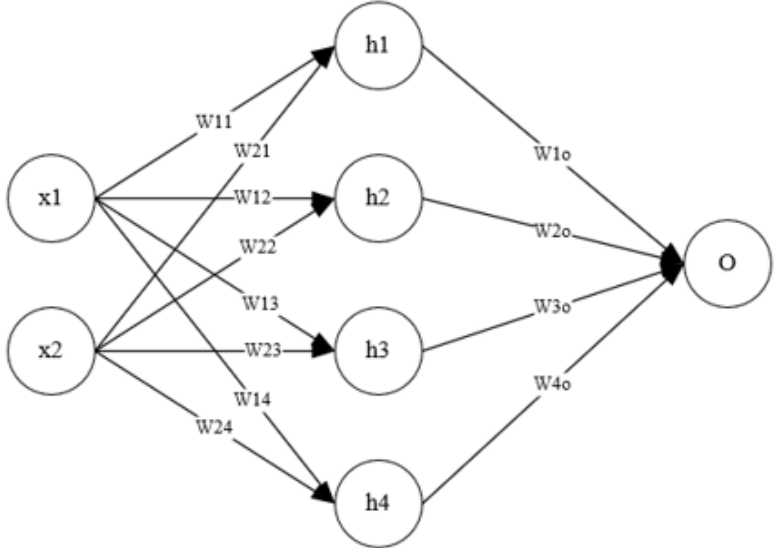

Gambar 4.

TF dua corpus akan mengisi lapisan input yaitu node $\mathrm{x} 1$ dan $\mathrm{x} 2$. Input $\mathrm{x} 1$ merupakan query atau objek data teks siswa yang diuji, sedangkan $\mathrm{x} 2$ merupakan input pembanding atau data teks siswa pembanding. Setelah itu, vektor kalimat ini diproses pada lapisan tersembunyi dengan empat neuron (h1, h2, h3, dan h4) menggunakan operasi TANH (Tangent Hyperbolic) sebagai fungsi aktivasi yang menghitung data input dengan bobot yang diinisialisasi terlebih dahulu.

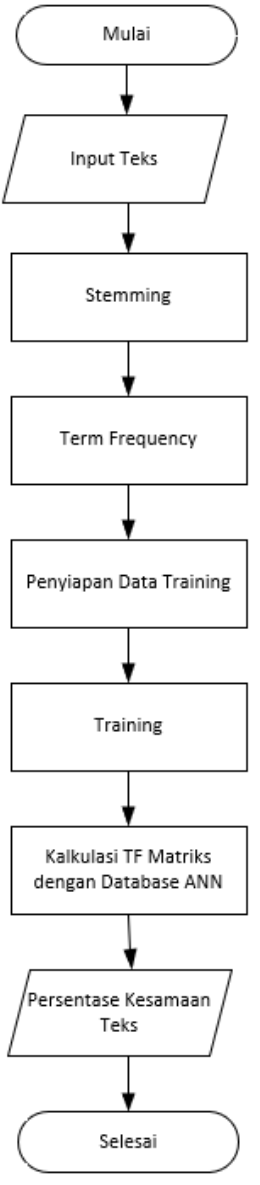

Gambar 3. Proses Perhitungan Kesamaan Teks dengan Artificia Neural Network

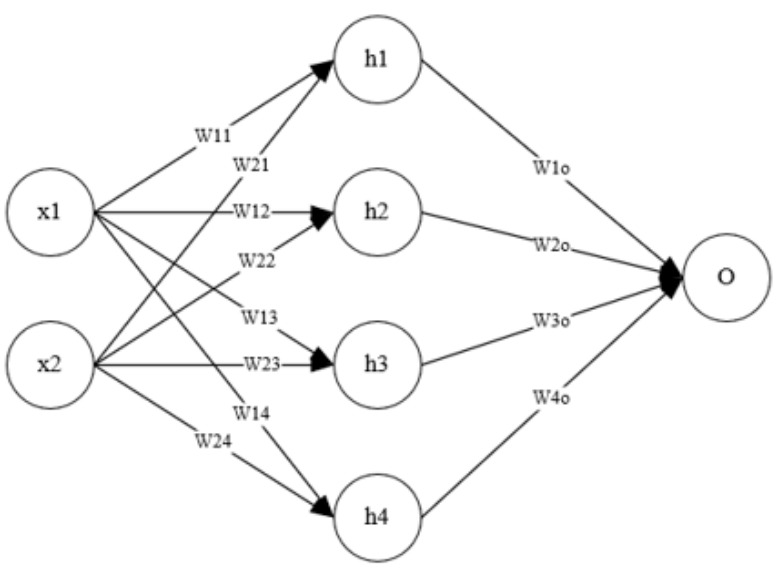

Gambar 4. Arsitektur neural network dalam penelitian ini

Proses ini kemudian akan mengulangi proses ini untuk mendapatkan bobot terkoreksi (W). Hasil perhitungan hidden layer dengan bobot (W10, W20, W30, dan W40) yang dihasilkan pada proses kedua kemudian menjadi nilai output (o). Proses ini dilakukan untuk membandingkan nilai prediksi dalam jaringan dengan setiap sampel data $(\mathrm{x})$ sehingga dapat memodifikasi hubungan bobot (w) dalam jaringan untuk bisa

DOI: https://doi.org/10.29207/resti.v5i6.3544 
mendapatkan nilai prediksi yang lebih dekat dengan y dibagi banyaknya x dan y dikurangi gabungan $\mathrm{x}$ dan $\mathrm{y}$. nilai sebenarnya [20][21]. Keluaran dari Indeks Jaccard memiliki tingkat kesamaan

ANN dalam penelitian ini menggunakan konsep AND Operator. Konsep AND Operator adalah memberikan keputusan antara dua nilai yang bernilai sama dan berbeda. Neural Network dengan AND Operator mampu memberikan keputusan tidak mutlak atau persentase sehingga jawaban dari proses kesamaan berupa persentase bukan 'ya' atau 'tidak'.

\subsubsection{Latent Semantic Indexing (LSI)} berkisar dari $0 \%$ hingga $100 \%$.

\section{Hasil dan Pembahasan}

\subsection{Fungsional Sistem}

\subsubsection{Hak Akses Sistem}

Sistem Tes Online dengan Deteksi Kesamaan Jawaban Essay Siswa yang dikembangkan dalam penelitian ini memiliki dua jenis akses yaitu Pengajar dan Siswa. Hak LSI adalah metode berbasis ruang vektor yang dapat akses Pengajar memiliki kewenangan dalam sistem yang membuat asosiasi antara dokumen yang terkait secara lebih luas daripada hak akses sebagai Siswa.

konseptual [22]. Metode ini mencakup teknik pengindeksan dan pencarian yang menggunakan fungsi matematika untuk mengidentifikasi hubungan antara istilah dan konsep dalam kumpulan teks yang tidak terstruktur. Teknik aljabar matriks yang disebut Singular Value Decomposition menghasilkan matriks dengan dimensi yang jauh lebih sedikit [23].

LSI adalah prinsip algoritmik yang digunakan oleh mesin pencari untuk memproses sinonim untuk memahami hubungan topik antara kata-kata [24]. Proses Singular Value Decomposition ditunjukkan pada

Gambar 5

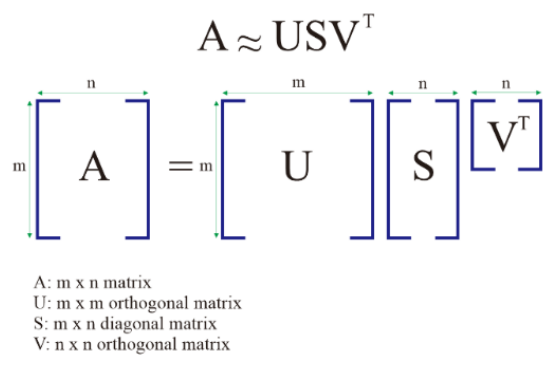

Sistem ini berbasis web yang bisa diakses melalui web browser dengan halaman login sebagai tampilan utama sistem ini, seperti terlihat pada Gambar 6.

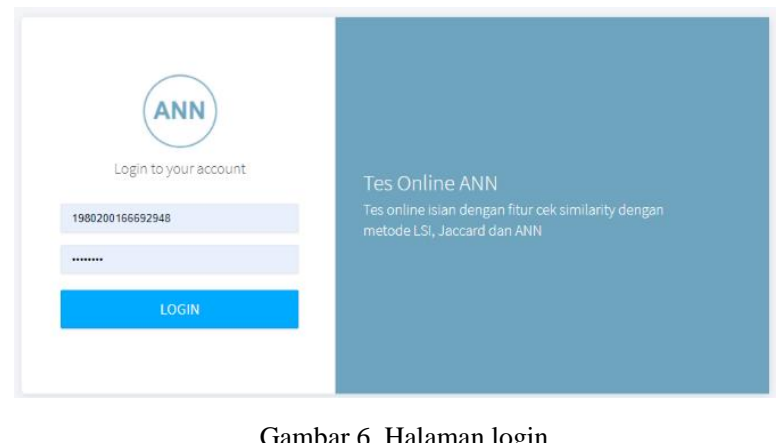

Setelah berhasil login, pengguna akan masuk ke dashboard dan dapat memilih mata pelajaran dan memilih menu lainnya yang sesuai dengan akses yang digunakan untuk masuk ke sistem.

\subsubsection{Registrasi Master Data Siswa, Mata Pelajaran dan Ujian}

Gambar 5. Singular Value Decomposition

LSI bertujuan untuk mendapatkan pemodelan yang efektif untuk merepresentasikan hubungan antara kata kunci dan dokumen yang dicari. Dari kumpulan kata kunci yang sebelumnya tidak lengkap dan tidak kompatibel ke sekelompok objek terkait.

\subsubsection{Jaccard Similarity}

Dalam tujuan pengelompokan dokumen, fungsi Koefisien Jaccard adalah salah satu metode yang terkenal. Jaccard juga dapat menghitung tingkat Setelah mendaftarkan siswa ke dalam mata pelajaran kesamaan antara dua kumpulan data yang disebut The yang diambil, Pengajar harus membuat sesi ujian. Jaccard Index [25]-[27]. Persamaan untuk menghitung Pembuatan sesi ujian tes berfungsi untuk membuat sesi kesamaan dengan Jaccard Index dapat dilihat pada ujian dalam suatu mata pelajaran agar ujian secara online Persamaan 4.

$$
\operatorname{Similarity}(X, Y)=\frac{|X \cap Y|}{|X|+|Y|-|X \cap Y|}
$$
dapat dilakukan sesuai dengan waktu yang telah ditentukan. kesamaan antara 2 data (x dan y), yaitu gabungan $\mathrm{x}$ dan

DOI: https://doi.org/10.29207/resti.v5i6.3544

Lisensi: Creative Commons Attribution 4.0 International (CC BY 4.0) 


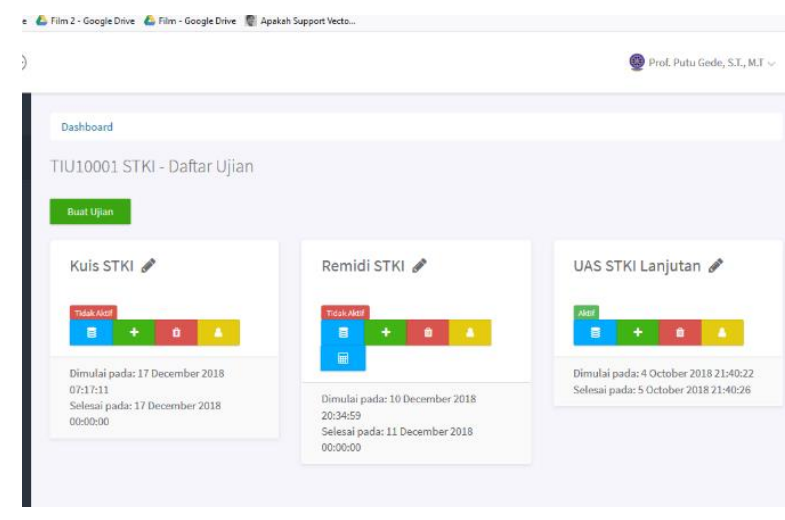

Gambar 7. Tampilan Sesi Ujian

Di sesi ujian, ada pilihan menu seperti yang ditampilkan pada Gambar 7. Fungsi pada tiap menu dapat dilihat pada Tabel 2.

\begin{tabular}{|c|c|c|}
\hline No. & Menu & Fungsi \\
\hline 1. & & $\begin{array}{l}\text { Melihat detail ujian seperti data soal dan } \\
\text { waktu mulai ujian. }\end{array}$ \\
\hline 2. & 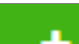 & Menambah soal pada ujian yang dipilih \\
\hline 3. & & Menghapus data ujian yang dipilih \\
\hline 4. & $\mathrm{C}$ & $\begin{array}{l}\text { Melihat jawaban dan persentase } \\
\text { kesamaan jawaban antar siswa }\end{array}$ \\
\hline 5. & 曲 & $\begin{array}{l}\text { Menu untuk melakukan proses kalkulasi } \\
\text { persentase kesamaan jawaban antar } \\
\text { siswa }\end{array}$ \\
\hline
\end{tabular}

Tampilan menu dengan bentuk icon dibuat untuk memudahkan pengguna memahami maksud dari menu.

\subsubsection{Menghitung Kesamaan Jawaban Siswa}

Pengukuran kesamaan jawaban siswa dihitung dengan menggunakan tiga metode yaitu ANN, LSI, dan Jaccard. Metode tersebut akan menghitung kesamaan jawaban setelah admin atau Pengajar menekan tombol hitung kesamaan pada sesi ujian. Khusus metode ANN diperlukan proses pelatihan untuk membentuk model dengan bobot ideal dan dipakai untuk melakukan proses pencocokan.

Setelah proses pelatihan selesai, sistem akan secara otomatis menguji kesamaan teks jawaban antara satu siswa dengan siswa lainnya dalam satu sesi ujian. Hasil kesamaan akan muncul berdasarkan metode yang digunakan untuk menghitung kesamaan, seperti terlihat pada Tabel 3.

Tabel 3 menunjukkan pengajar yang menggunakan sistem ini dapat langsung melihat kesamaan jawaban antara satu siswa dengan siswa lainnya. Para Pengajar dapat menggunakannya sebagai salah satu pertimbangan penting dalam menilai essay siswa dengan melihat kejujuran siswa dalam menjawab.

Tabel 3. Hasil Persentase Kesamaan Teks Pada Tiap Metode

\begin{tabular}{|c|c|c|c|c|}
\hline ID & Nama Siswa & LSI & Jaccard & $\begin{array}{c}\text { Neural } \\
\text { Network }\end{array}$ \\
\hline $\mathrm{A}$ & $\begin{array}{l}\text { Agung Adhika Mas } \\
\text { Pratama }\end{array}$ & $24.6 \%$ & $20.5 \%$ & $24.2 \%$ \\
\hline B & $\begin{array}{l}\text { Made Satya Wibawa Esa } \\
\text { Narendra }\end{array}$ & $33.1 \%$ & $25.0 \%$ & $31.2 \%$ \\
\hline $\mathrm{C}$ & I Putu Gede Adi Khusuma & $30.4 \%$ & $23.9 \%$ & $28.4 \%$ \\
\hline $\mathrm{D}$ & $\begin{array}{l}\text { Kadek Effa Krisma } \\
\text { Buriartha }\end{array}$ & $33.6 \%$ & $19.6 \%$ & $26.8 \%$ \\
\hline $\mathrm{E}$ & Kadek Lanang Mahardika & $26.4 \%$ & $26.7 \%$ & $32.0 \%$ \\
\hline $\mathrm{F}$ & I Gede Widya Antar Nusa & $18.8 \%$ & $24.6 \%$ & $27.7 \%$ \\
\hline $\mathrm{G}$ & Diego Tristan Nababan & $23.2 \%$ & $17.9 \%$ & $22.2 \%$ \\
\hline $\mathrm{H}$ & Angga Destia Faturrahman & $35.2 \%$ & $23.9 \%$ & $28.4 \%$ \\
\hline I & $\begin{array}{l}\text { I Gede Nyoman Ambara } \\
\text { Yasa }\end{array}$ & $27.2 \%$ & $18.3 \%$ & $25.0 \%$ \\
\hline $\mathrm{J}$ & Jibril Ali Akbar & $29.9 \%$ & $26.1 \%$ & $30.8 \%$ \\
\hline $\mathrm{K}$ & $\begin{array}{l}\text { Michael Shummaecer } \\
\text { Purba }\end{array}$ & $21.5 \%$ & $18.9 \%$ & $23.0 \%$ \\
\hline $\mathrm{L}$ & Kadek Eka Yuda Trisna S & $36.3 \%$ & $35.8 \%$ & $40.2 \%$ \\
\hline M & Adib humaid wajiih & $30.6 \%$ & $24.7 \%$ & $27.6 \%$ \\
\hline $\mathrm{N}$ & $\begin{array}{l}\text { I Dewa Gede Suryadiantha } \\
\text { Wedagama }\end{array}$ & $33.1 \%$ & $27.3 \%$ & $31.4 \%$ \\
\hline $\mathrm{O}$ & Fahri Choirul Anam & $29.8 \%$ & $26.9 \%$ & $32.4 \%$ \\
\hline $\mathrm{P}$ & $\begin{array}{l}\text { Gusti Arya Agung Adi } \\
\text { Rahaditya }\end{array}$ & $24.1 \%$ & $17.5 \%$ & $22.3 \%$ \\
\hline Q & $\begin{array}{l}\text { Ni Made Tara Okta } \\
\text { Adriana }\end{array}$ & $39.7 \%$ & $27.0 \%$ & $33.0 \%$ \\
\hline $\mathrm{R}$ & $\begin{array}{l}\text { Ketut Mediana Ayu } \\
\text { Candrayani }\end{array}$ & $42.3 \%$ & $32.7 \%$ & $38.3 \%$ \\
\hline \multirow[t]{2}{*}{$\mathrm{S}$} & $\begin{array}{l}\text { I Gusti Agung Surya } \\
\text { Pramana w }\end{array}$ & $19.5 \%$ & $28.8 \%$ & $29.8 \%$ \\
\hline & MAPE $(\%)$ & $28.0 \%$ & $0.0 \%$ & $20.0 \%$ \\
\hline
\end{tabular}

\subsection{Experimental Setup}

Proses pengujian metode similarity dengan ANN, LSI, dan Jaccard menggunakan data input berupa corpus yang diambil dari ujian essay siswa dari salah satu program studi di universitas X. Dalam sesi ujian essay dibuat lima pertanyaan yang sudah dijawab oleh siswa.

Jumlah data yang digunakan adalah 100 corpus jawaban essay. Khusus untuk metode ANN yang memerlukan data latih diambil dari corpus jawaban siswa lainnya yang diperbandingkan dalam satu sesi ujian.

Dalam proses pelatihan, metode ANN menggunakan beberapa parameter. Konsep operator AND digunakan dalam pembuatan fitur knowledge data latih. Nilai 0 ketika bertemu 1 memiliki output 0 , nilai 1 dan 1 memiliki 1. Nilai TF dikonversi menjadi $-1 ; \ldots ; 1$ karena library neural network yang digunakan menggunakan nilai input dengan range -1 sampai 1 . Parameter yang digunakan dalam pelatihan dapat dilihat pada

Tabel 4.

Tabel 4. Nilai yang digunakan pada Parameter ANN

\begin{tabular}{lc}
\hline Parameter & Value \\
\hline Learning Rate & 0.1 \\
Momentum & 0.2 \\
Round & 1000 \\
\hline
\end{tabular}

DOI: https://doi.org/10.29207/resti.v5i6.3544

Lisensi: Creative Commons Attribution 4.0 International (CC BY 4.0) 
I Made Suwija Putra, Putu Jhonarendra, Ni Kadek Dwi Rusjayanthi Jurnal RESTI (Rekayasa Sistem dan Teknologi Informasi) Vol. 5 No. 6 (2021) 1070 - 1082

\begin{tabular}{lc}
\hline Error Rate & 0.01 \\
Epoch & 100 \\
\hline
\end{tabular}

Learning rate adalah nilai yang mempengaruhi akurasi dan output yang diharapkan dari setiap epoch. Learning rate juga menentukan berapa banyak pembaruan yang dilakukan pada bobot selama pelatihan. Momentum adalah parameter yang menentukan banyak nilai yang dapat ditoleransi dalam memenuhi suatu kondisi. Round adalah jumlah pengulangan pelatihan (algoritma Backpropagation). Epoch adalah jumlah iterasi dari Round.

Penentuan value dari tiap parameter ditentukan berdasarkan percobaan yang sebelumnya dilakukan dengan ketentuan dasar nilai parameter disesuaikan pada data yang hendak dilatih. Hasil pelatihan yang memberikan nilai terbaik ditetapkan sebagai parameter dalam metode ANN. Setelah proses pelatihan, nilai NN dicari berdasarkan data pelatihan dengan bobot yang telah diperoleh dan memenuhi kondisi di bawah Error Rate yang ditentukan yaitu 0.01. Kemudian, menyimpan nilai NN ke database. Nilai TF yang diperoleh di-inputkan ke dalam NN untuk mendapatkan nilai kesamaan jawaban. Hasil output metode ANN adalah persentase kesamaan antar dua buah text.

Dalam penelitian ini proses evaluasi hasil menggunakan konsep evaluasi metode MAPE (Mean Absolute Percentage Error), yaitu dengan membandingkan nilai yang dihasilkan dari masing-masing metode (forecast) dengan nilai referensi yang ditentukan (actual), seperti yang ditunjukkan pada Persamaan 5.

MAPE $=\left(\frac{1}{n} \sum \frac{\mid \text { Actual-Forecast } \mid}{\mid \text { Actual } \mid}\right) * 100$

Kami memilih metode MAPE sebagai metode evaluasi kinerja metode ANN dalam tugas mengukur similarity text, karena tugas pedeteksian similarity text dalam penelitian lebih kepada proses untuk memprediksi hasil kesamaan antar teks jawaban mahasiswa. Besar hasil persentase tingkat kesamaan antar jawaban mahasiswa tentunya tidak diketahui sebelumnya besaran hasilnya pada

dan hasil persentase tingkat kesamaan text dalam

penelitian ini tergantung dari jawaban mahasiswa yang Gambar 8 . diperbandingkan, data latih jawaban mahasiswa dan pendekatan metode yang digunakan. Sehingga secara proses hal ini tidak sama seperti tugas klasifikasi objek, yang dimana sudah ditentukan sebelumnya label untuk setiap data latih maupun ujinya. sehingga jika menggunakan metode evaluasi confusion matrix menjadi tidak relevan lagi dalam penelitian ini. Oleh karena itu, menurut kami MAPE bisa sebagai opsi dalam mengukur kinerja metode dengan menghasilkan nilai error dari metode ANN dan LSI terhadap nilai actual yang dijadikan acuan yaitu metode Jaccard Similarity.

Metode Jaccard pada penelitian ini digunakan sebagai acuan atau nilai aktual untuk mengukur metode lainnya, hal ini berdasarkan pertimbangan pada studi-studi yang ada, metode Jaccard Similarity adalah metode yang populer dan masih memiliki kinerja yang efektif dan baik untuk menentukan kesamaan teks dengan fitur sintaksis kata [29] [30]. Sehingga berdasarkan Persamaan 5, variabel actual adalah nilai semua data tingkat kesamaan yang dihasilkan oleh metode Jaccard. Variabel forecast adalah nilai dari setiap tingkat kesamaan data dengan metode LSI dan ANN. Kemudian, nilai tersebut dirata-ratakan dan digunakan sebagai persentase MAPE.

Ada beberapa percobaan yang akan dilakukan untuk menguji metode ANN dalam melakukan tugas mendeteksi kesamaan teks, yaitu percobaan utama dengan menggunakan data latih konversi 4 nilai TF dan data latih konversi 8 nilai TF yang sama-sama menggunakan fungsi aktivasi Tanh pada hidden layer (hasil dapat dilihat pada bagian 3.3). Selain itu ada percobaan tambahan yang mengujikan pengaruh fungsi aktivasi pada ANN terhadap tugas mendeteksi kesamaan teks, percobaan ini membandingkan hasil dari fungsi Tanh, ReLU, dan Sigmoid (hasil dapat dilihat pada bagian 3.4 .

\subsection{Hasil Percobaan Utama}

Hasil utama penelitian ini berfokus seberapa dekat hasil pencocokan kata dalam corpus teks jawaban siswa yang satu dengan jawaban siswa yang lain dalam satau sesi ujian dengan menggunakan metode ANN dibandingkan dengan metode LSI. Objek siswa yang akan diukur tingkat kesamaannya dinamakan dengan istilah "Query". Sedangkan istilah "Input" digunakan untuk objek siswa yang digunakan untuk perbandingan dengan "Query".

Misalnya, Dalam pengujian penelitian ini akan mencari tingkat kesamaan jawaban dari siswa bernama Septiana Eka Arwanda Riski, maka jawaban siswa tersebut dilabeli sebagai "Query" (x1), kemudian dilakukan proses preprocessing. Hasil preprocessing dapat dilihat

Query

rencana, planning, adalah, giat, yang, laku, untuk, tentu, arah, tuju, dan, target, usaha, dengan, susun, strategi, untuk, tentu, apa, saja, sumber, daya, yang, butuh, dalam, capai, tuju, sama, organisasi, organizing, adalah, giat, untuk, tentu, bagaimana, susun, organisasi, usaha, dalam, tentu, job, desciption, dan, wenang, dalam, anggota, usah, dalam, jalan, aktivitas, yang, sudah, rencak, arah, directing, adalah, giat, untuk, tuntun, motivasi, dan, beri, pengaraha, kepada, anggota, usaha, dalam, jalan, giat, dan, aktivitas, apa, saja, dalam, capai, tuju, sama, jadi, dalam, arah, ini, butuh, orang, leader, controlling, awas, adalah, giat, untuk, memonitoring, dari, tiap, giat, yang, laku, untuk, kendali, jika, jadi, simpang, dalam, jalan, giat, dan, baik, dari, simpang, yang, sudah, jadi,

Gambar 8. Hasil Preprocessing Query

DOI: https://doi.org/10.29207/resti.v5i6.3544

Lisensi: Creative Commons Attribution 4.0 International (CC BY 4.0) 
Sedangkan yang menjadi label "Input" (x2) adalah tidak hanya bernilai 0 dan 1, bisa saja nilai yang muncul masing-masing teman dari "Septiana Eka Arwanda 2, 3, dan 4, dst. Sehingga hal ini tentunya perlu Riski", misalnya jawaban siswa lain yang bernama dikonversi menjadi rentang nilai yang bisa dikerjakan “Agung Adhika Mas Pratama". Proses preprocessing oleh operator AND pada hidden layer ANN pada juga dilakukan pada label "Input". Contoh hasil penelitian ini. Oleh karena itu, percobaan pertama ini, preprocessing jawaban "Agung Adhika Mas Pratama” menggunakan data latih yang mengambil nilai TF yang terlihat pada

Gambar 9.

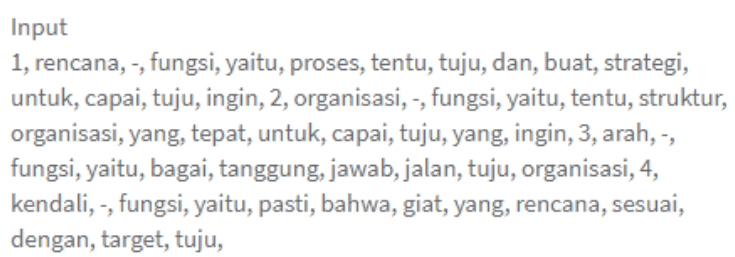

Gambar 9. Hasil Preprocessing Input

bernilai mulai dari 0 sampai 4 . Konversi 4 Nilai TF ditampilkan seperti pada Tabel 6 .

\begin{tabular}{cc} 
Tabel 6 Konversi 4 & Nilai TF terhadap Input Neural Network \\
\hline TF & Nilai Input Neural Network \\
\hline 0 & -1 \\
1 & -0.5 \\
2 & 0 \\
3 & 0.5 \\
4 & 1 \\
\hline
\end{tabular}

Setelah proses pelatihan selesai dan menghasilkan Dari dua input yang ada tersebut, kemudian sistem model pelatihan, proses selanjutnya adalah pengujian menghitung TF untuk setiap suku kata di masing- dengan dua vektor kalimat "query" dan "input". Kedua masing corpus seperti pada Persamaan 1. Setelah itu, vektor ini mengandung nilai frekuensi. Proses sistem menandai untuk setiap kata yang beririsan pencocokan dilakukan dengan fungsi aktivasi Tanh yang dengan melihat kata yang sama muncul di kedua input. dihitung dengan bobot yang disesuaikan pada saat Hasilnya ditampilkan pada Tabel 5.

Tabel 5. Irisan Kata

\begin{tabular}{llll}
\hline Kata & Query & Input & Irisan \\
\hline rencana & 1 & 2 & 1 \\
giat & 7 & 1 & 1 \\
yang & 5 & 3 & 1 \\
untuk & 6 & 2 & 1 \\
tentu & 4 & 2 & 1 \\
arah & 3 & 1 & 1 \\
tuju & 3 & 5 & 1 \\
dan & 5 & 1 & 1 \\
target & 1 & 1 & 1 \\
dengan & 1 & 1 & 1 \\
strategi & 1 & 1 & 1 \\
capai & 2 & 2 & 1 \\
organisasi & 2 & 3 & 1 \\
jalan & 3 & 1 & 1 \\
kendali & 1 & 1 & 1 \\
\hline
\end{tabular}

Proses selanjutnya menghitung tingkat kesamaan sesuai dengan masing-masing metode yaitu ANN, LSI, dan Jaccard. Proses pendeteksian kesamaan teks menggunakan metode ANN memiliki pendekatan yang berbeda dengan LSI dan Jaccard. Proses pelatihan diperlukan untuk dapat menghasilkan nilai pencocokan kata dengan fungsi AND. Hasil pelatihan menghasilkan nilai bobot paling optimal untuk operasi AND.

Terdapat 2 percobaan dalam mengukur kinerja dari metode ANN. Seperti yang telah disebutkan sebelumnya, fitur pembeda antara teks yang satu dengan yang lainnya adalah jumlah kemunculan kata. Sehingga nilai TF menjadi input pada ANN untuk dilakukan pencocokan.

\subsubsection{Konversi 4 Nilai TF}

Percobaan pertama yang dilakukan adalah menggunakan data latih konversi 4 nilai TF. Nilai TF Percobaan lainnya dilakukan kembali untuk mengukur dalam proses preprocessing yang dihasilkan tentunya efektifitas data latih terhadap kemampuan ANN dalam

proses backpropagation. Kemudian, nilai ini diteruskan ke lapisan output untuk menghasilkan persentase kesamaan antara dua teks yang diuji.

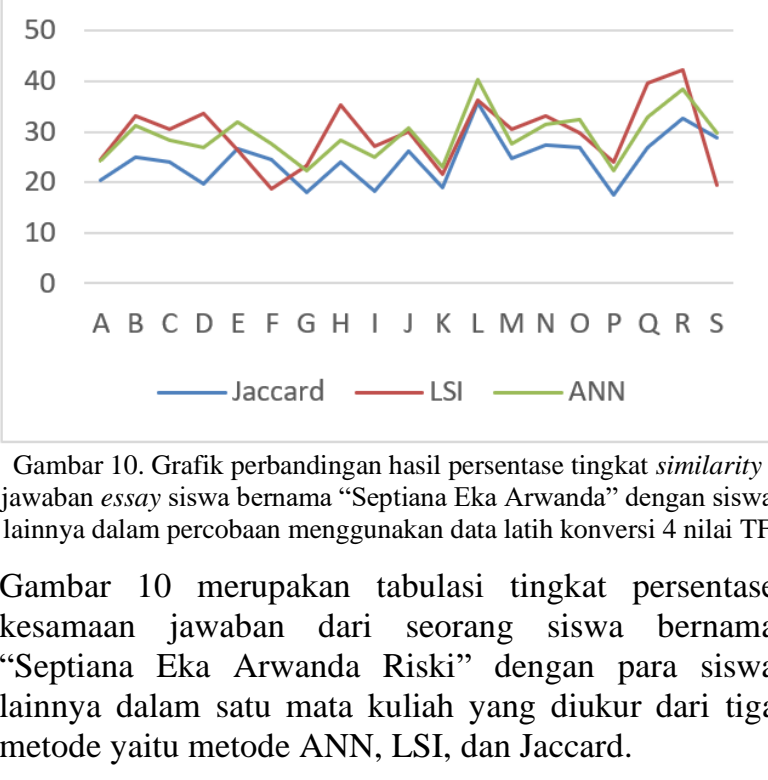

Hasil persentase tingkat kesamaan dari metode ANN terlihat mendekati hasil tingkat kesamaan metode Jaccard jika dibandingkan dengan metode LSI. Hal ini juga dibuktikan dengan nilai MAPE (Persamaan 5), dihasilkan Nilai MAPE untuk metode ANN lebih kecil dibandingan dengan nilai MAPE yang dihasilkan metode LSI terhadap Metode Jaccard. Nilai MAPE untuk percobaan ini dapat dilihat pada Tabel 3

\subsubsection{Konversi 8 Nilai TF}

DOI: https://doi.org/10.29207/resti.v5i6.3544 
melakukan tugas perhitungan persentase kesamaan text. menunjukkan bahwa metode ANN dapat diandalkan Percobaan ini menggunakan data latih tambahan yaitu pada tugas pendeteksian kesamaan dua teks yang konversi 8 nilai TF. kinerjanya mendekati metode Jaccard dibandingkan

Basis pengetahuan ANN menggunakan 4 nilai TF masih dengan metode LSI.

terbilang kurang bisa mencakup keseluruhan Sebagai catatan, hasil tingkat kesamaan teks pada kemungkinan nilai TF yanga ada, karena banyak data metode ANN, tidak akan menghasilkan nilai tingkat yang memiliki nilai TF lebih dari 4, sehingga ANN kesamaan teks yang tetap untuk objek teks yang sama kurang akurat dalam memberi keputusan jika ditemukan untuk setiap sesi perhitungan yang berbeda. Hal ini nilai TF lebih dari 4. Oleh karena itu pada percobaan ini dipengaruhi oleh nilai inisialisasi parameter yang ditentukan data latih dengan dengan konversi 8 Nilai TF diberikan dalam Tabel 4, activation function, dan proses seperti yang ditampilkan pada Tabel 7.

\begin{tabular}{cc} 
Tabel 7 Konversi 8 Nilai TF terhadap Input Neural Network \\
\hline TF & Nilai Input Neural Network \\
\hline 0 & -1 \\
1 & -0.75 \\
2 & -0.5 \\
3 & -0.25 \\
4 & 0 \\
5 & 0.25 \\
6 & 0.5 \\
7 & 0.75 \\
8 & 1 \\
\hline
\end{tabular}
perbaikan untuk bobot yang terbentuk pada proses backpropagation. Sedangkan untuk metode LSI dan Jaccard memberikan nilai tetap untuk pengukuran berulang dalam satu objek karena proses pehitungannya menggunakan persamaan matematika yang sudah ditetapkan.

\subsection{Hasil Percobaan Tambahan}

\subsubsection{Analisis Pengujian Fungsi Aktivasi}

Percobaan tambahan dilakukan dengan tujuan menguji efektifitas activation function pada ANN dalam memberikan keputusan akhir. Selain aktivasi Tanh yang digunakan pada percobaan utama sebelumnya, pada percobaan ini juga menggunakan fungsi aktivasi lainnya yaitu ReLU dan Sigmod. Masing-masing fungsi aktivasi diujikan agar bisa melihat dan memperbandingkan hasil tingkat persentase kesamaan text yang dihasilkan, sehingga bisa dianalisa fungsi aktivasi yang mana lebih baik kinerjanya untuk metode ANN pada penelitian ini. siswa untuk ANN yang menggunakan data latih konversi 4 Nilai TF (ANN4) dengan ANN yang menggunakan konversi 8 Nilai TF (ANN8) untuk percobaan ini ditampilkan pada grafik Gambar 11.

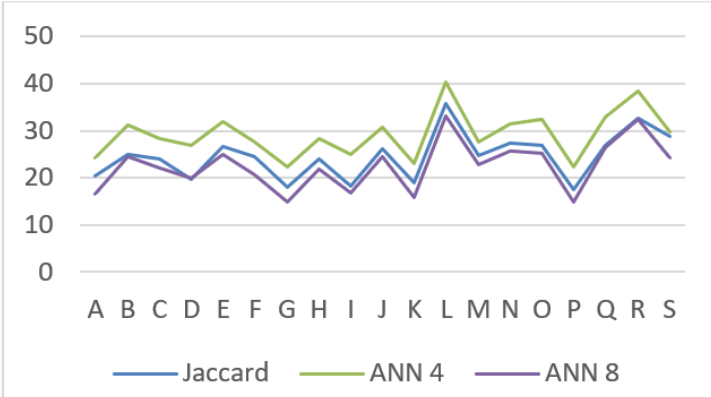

Gambar 11. Grafik perbandingan hasil persentase tingkat similarity jawaban essay siswa bernama "Septiana Eka Arwanda" dengan siswa lainnya dalam percobaan menggunakan data latih konversi 8 nilai TF.

Secara keseluruhan dari hasil-hasil dua percobaan utama yang dilakukan dapat dianalisa bahwa dengan menambahkan data latih yang basis pengetahuan nilai konversi TF nya lebih lebar untuk metode ANN menghasilkan persentase MAPE yang lebih kecil, yang menandakan kemampuan ANN semakin mendekati hasil persentase dari metode Jaccard dalam melakukan tugas pendeteksian similarity text. Hasil ini juga

Pengujian aktivasi ini dilakukan dengan data latih konversi 8 nilai TF dengan pengaturan inisialisasi nilai parameter sama seperti pada Tabel 4.

Tabel 8 Nilai MAPE Pengujian Aktivasi

\begin{tabular}{cc}
\hline Aktivasi & MAPE \\
\hline Tanh & $8.9 \%$ \\
ReLU & $0.2 \%$ \\
Sigmoid & $47.8 \%$ \\
\hline
\end{tabular}

Pengujian fungsi aktivasi ini juga menggunakan objek siswa dan sesi ujian yang sama seperti pada percobaan utama, dengan tugas utama yaitu mengukur tingkat kesamaan jawaban essay siswa bernama "Septiana Eka Arwanda Riski" terhadap siswa lainnya. Tabel 8 menampilkan nilai MAPE pada pengujian fungsi aktivasi ANN. Aktivasi Tanh memperoleh nilai MAPE sebesar $8.9 \%$, sedangkan ReLU $0.1 \%$ dan Sigmoid $47.8 \%$.

Gambar 12 menampilkan perbandingan detail persentase kesamaan jawaban antar siswa pada metode ANN dengan fungsi aktivasi yang berbeda. Terlihat aktivasi ReLU lebih berhimpitan dengan metode Jaccard dibandingkan aktivasi Tanh yang masih terlihat penyimpangannya. Sedangkan aktivasi Sigmoid memiliki penyimpangan terjauh dengan metode Jaccard 
yang sebagai nilai faktual. Hal ini menggambarkan terhadap efektivitas deteksi tingkat similarity karena bahwa fungsi ReLU lebih baik dari fungsi aktivasi Hasil tingkat similaritynya mendekati hasil Jaccard lainnya sesuai dengan nilai MAPE yang dihasilkan similarity dengan perolehan nilai MAPE 0,07\%. Namun, paling kecil.

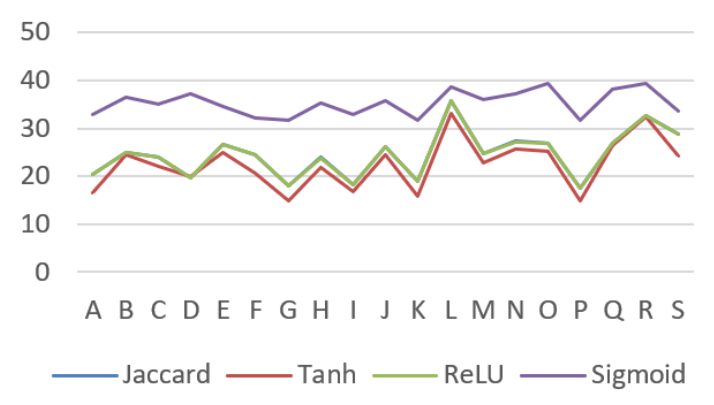

Gambar 12. Grafik hasil perbandingan fungsi aktivasi ANN (Tanh, ReLU, dan Sigmoid terhadap nilai acuan persentase tingkat kesamaan text pada metode Jaccard

\subsubsection{Analisis Pengujian Model Neural Network}

Percobaan tambahan dilakukan dengan menguji model ANN lainnya dengan dengan menambahkan 1 hidden layer dari model sebelumnya. Penambahan hidden layer sehingga menjadi lebih dari satu hidden layer seperti pada Gambar 13 sering disebut dengan arsitektur MLP (Multi-Layer Perceptron) [31] [32].

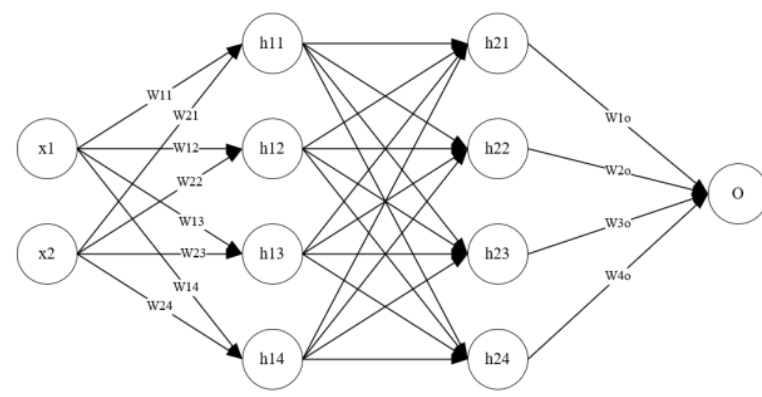

Gambar 13. Arsitektur neural network dengan tambahan 1 hidden layer

Gambar 13 menampilkan model MLP dengan 2 hidden layer dimana tiap hidden layer berisi 4 node. Pengujian dilakukan dengan data dan pengaturan yang sama seperti yang dijelaskan pada sub bagian 3.2. Dari pengujian yang dilakukan didapatkan hasil pengujian seperti terlihat pada Tabel 9 .

Tabel 9 Nilai MAPE Pengujian Model

\begin{tabular}{ccc}
\hline Model & Waktu Pelatihan & MAPE \\
1 Hidden & 2.32 detik & $0.26 \%$ \\
$\begin{array}{c}\text { Layer } \\
2 \text { Hidden } \\
\text { Layer }\end{array}$ & 26.97 detik & $0.07 \%$ \\
\hline
\end{tabular}

Tabel 9 merupakan hasil pengujian kinerja ANN dengan penelitian ini.

dengan model MLP. Terlihat nilai MAPE yang didapat dari model MLP lebih kecil dari metode ANN dengan 1 hidden layer. Hal ini menandakan metode ANN dengan menggunakan model MLP memiliki dampak positif masa waktu pelatihan dengan menggunakan model MLP jauh lebih lama dibandingkan ANN yang menggunakan 1 hidden layer. Hal ini disebabkan semakin rumit node jaringan Neural Network, semakin banyak komputasi penyesuaian bobot yang dilakukan sehingga kebutuhan waktu pemrosesan semakin meningkat.

Secara keseluruhan dari percobaan tambahan yang dilakukan ini, menandakan bahwa ketepatan pemilihan fungsi aktivasi, serta penambahan hidden layer pada arsitektur metode ANN memiliki kontribusi penting dalam peningkatan efektivitas kinerja metode ANN untuk menghasilkan persentase tingkat kesamaan sebuah text. Hal ini dibuktikan dengan persentase tingkat similarity lebih mendekati hasil dari metode acuan yaitu Jaccard Similarity.

\section{Kesimpulan}

Sistem Pendeteksi Kesamaan Jawaban Essay Siswa yang dibangun dalam penelitian ini berhasil mengadopsi konsep fungsional e-learning, seperti pengelolaan data siswa, pengelolaan data Pengajar, pengelolaan data mata pelajaran, dan pengelolaan tugas siswa.

Penelitian ini berhasil mengimplementasikan fitur mendeteksi kesamaan text menggunakan metode ANN dengan arsitektur 3-layer: input, hidden, dan output layer. Operator yang digunakan adalah AND dengan fungsi aktivasi pada hidden layer. Dalam mengevaluasi kinerja metode ANN, digunakan metode MAPE, dengan menetapkan metode Jaccard sebagai nilai aktualnya. Hasil persentase MAPE pada metode ANN yang paling baik adalah $0.07 \%$ yang didapat dengan menggunakan fungsi aktivasi ReLU dan dengan model aristektur MLP. Sedangkan nilai MAPE metode LSI adalah 28,0\%. Hasil ini menunjukkan bahwa kinerja metode ANN lebih efektif dibandingkan dengan LSI dalam tugas pendeteksian kesamaan teks karena memiliki kinerja yang mendekati metode Jaccard yang dikenal sebagai metode similarity yang andal dalam fitur sintaksis kata. Pekerjaan selanjutnya yang bisa dilakukan adalah mengembangkan metode ANN untuk bisa mendeteksi kesamaan text baik itu secara lexical maupun semantic.

\section{Ucapan Terimakasih}

Terima kasih kepada Universitas Udayana yang telah memberikan dukungan berupa hibah untuk penelitian ini dan pihak-pihak yang telah membantu menyelesaikan

\section{Daftar Rujukan}

[1] G. Strimel and M. E. Grubbs, "Positioning technology and engineering education as a key force in STEM education," $J$.

DOI: https://doi.org/10.29207/resti.v5i6.3544

Lisensi: Creative Commons Attribution 4.0 International (CC BY 4.0) 
Technol. Educ., 2016, doi: 10.21061/jte.v27i2.a.2.

[2] W. He, Z. (Justin) Zhang, and W. Li, "Information technology solutions, challenges, and suggestions for tackling the COVID19 pandemic," Int. J. Inf. Manage., vol. 57, 2021, doi: 10.1016/j.ijinfomgt.2020.102287.

[3] G. Sakarkar, "Intelligent Online e-Learning Systems: A Comparative Study," vol. 56, no. 4, pp. 21-25, 2012.

[4] A. Shah and S. Jain, "An Agent based Personalized Intelligent elearning," Int. J. Comput. Appl., 2011, doi: 10.5120/24113215 .

[5] E. L. Amalia, A. J. Jumadi, I. A. Mashudi, and D. W. Wibowo, "Analisis Metode Cosine Similarity Pada Aplikasi Ujian Online Otomatis (Studi Kasus JTI POLINEMA)," J. Teknol. Inf. dan Ilmu Komput., vol. 8, no. 2, p. 343, 2021, doi: 10.25126/jtiik.2021824356.

[6] N. M. A. Lestari and M. Sudarma, "Perencanaan Search Engine E-commerce dengan Metode Latent Semantic Indexing Berbasis Multiplatform," Lontar Komput. J. Ilm. Teknol. Inf., vol. 8, no. 1, p. 31, 2017, doi: 10.24843/lkjiti.2017.v08.i01.p04.

[7] K. Selvi and R. M. Suresh, "Context similarity measure using fuzzy formal concept analysis," in ACM International Conference Proceeding Series, 2012, pp. 420-426, doi: $10.1145 / 2393216.2393287$.

[8] P. Neculoiu, M. Versteegh, and M. Rotaru, "Learning Text Similarity with Siamese Recurrent Networks," Aug. 2016, pp. 148-157, doi: 10.18653/v1/w16-1617.

[9] Y. L. Joane, A. Sinsuw, and A. Jacobus, "Rancang Bangun Aplikasi Deteksi Kemiripan Dokumen Teks Menggunakan Algoritma Ratcliff/Obershelp," J. Tek. Inform., vol. 11, no. 1, 2017, doi: 10.35793/jti.11.1.2017.17654.

[10] N. Alamsyah, "Deteksi Plagiarisme Tingkat Kemiripan Judul Skripsi Dengan Algoritma Winnowing," Technol. J. Ilm., vol. 8, no. 4, p. 205, 2017, doi: 10.31602/tji.v8i4.1119.

[11] N. E. Diana and I. Hanana Ulfa, "Measuring performance of ngram and jaccard-similarity metrics in document plagiarism application," in Journal of Physics: Conference Series, 2019, vol. 1196, no. 1, doi: 10.1088/1742-6596/1196/1/012069.

[12] D. Thorleuchter, D. Van Den Poel, and A. Prinzie, "Mining ideas from textual information," Expert Syst. Appl., vol. 37, no. 10, 2010, doi: 10.1016/j.eswa.2010.04.013.

[13] E. Iftikhar, A. Iftikhar, and M. K. Mehmood, "Identification of textual entailments in business rules," 2016 6th Int. Conf. Innov. Comput. Technol. INTECH 2016, pp. 706-711, 2017, doi: 10.1109/INTECH.2016.7845104.

[14] A. W. Pradana and M. Hayaty, "The Effect of Stemming and Removal of Stopwords on the Accuracy of Sentiment Analysis on Indonesian-language Texts," Kinet. Game Technol. Inf. Syst. Comput. Network, Comput. Electron. Control, 2019, doi: 10.22219/kinetik.v4i4.912.

[15] J. Wibowo, "Aplikasi Penentuan Kata Dasar Dari Kata Berimbuhan Pada Kalimat Bahasa Indonesia Dengan Algoritma Stemming," J. Ris. Komput., vol. 3, no. 5, 2016.

[16] M. A. Rosid, A. S. Fitrani, I. R. I. Astutik, N. I. Mulloh, and H. A. Gozali, "Improving Text Preprocessing for Student Complaint Document Classification Using Sastrawi," in IOP Conference Series: Materials Science and Engineering, 2020, vol. 874, no. 1, doi: 10.1088/1757-899X/874/1/012017.

[17] S. Fahmi, L. Purnamawati, G. F. Shidik, M. Muljono, and A. Z. Fanani, "Sentiment analysis of student review in learning management system based on sastrawi stemmer and SVMPSO,” 2020, doi: 10.1109/iSemantic50169.2020.9234291.

18] I. M. Suwija Putra, Y. Adiwinata, D. P. Singgih Putri, and N. P. Sutramiani, "Extractive Text Summarization of Student Essay Assignment Using Sentence Weight Features and Fuzzy CMeans," Int. J. Artif. Intell. Res., vol. 5, no. 1, pp. 13-24, 2021, doi: 10.29099/ijair.v5i1.187.

[19] S. Harvey and R. Harvey, "An introduction to artificial intelligence," Appita J., vol. 51, no. 1, 1998, doi: 10.2514/6.1994-294.

[20] M. A. Hanafiah, N. L. W. S. R. Ginantra, and A. D. GS, "Analysis of ANN Backpropagation Ability to Predict Expenditure Group Inflation," IJISTECH (International J. Inf. Syst. Technol., vol. 4, no. 2, 2020, doi: 10.30645/ijistech.v4i2.103.

[21] D. Marlina and F. Arifin, "Predicting The Number of Tourists Based on Backpropagation Algorithm," RESTI J. (System Eng. Inf. Technol., vol. 5, no. 3, pp. 439 - 445, 2021, doi: https://doi.org/10.29207/resti.v5i3.3061.

[22] T. Hofmann, "Probabilistic Latent Semantic Indexing," ACM SIGIR Forum, vol. 51, no. 2, 2017, doi: 10.1145/3130348.3130370.

[23] R. Anita, C. N. Subalalitha, A. Dorle, and K. Venkatesh, "Semantic search using Latent Semantic Indexing and Word Net," ARPN J. Eng. Appl. Sci., vol. 12, no. 2, 2017.

24] M. S. Hasibuan, L. E. Nugroho, and P. I. Santosa, "Model detecting learning styles with artificial neural network," $J$. Technol. Sci. Educ., vol. 9, no. 1, 2019, doi: 10.3926/jotse.540.

[25] M. Halkidi, Y. Batistakis, and M. Vazirgiannis, "Cluster validity methods: Part I," SIGMOD Record, vol. 31, no. 2. 2002, doi: $10.1145 / 565117.565124$.

[26] S. Niwattanakul, J. Singthongchai, E. Naenudorn, and S. Wanapu, "Using of jaccard coefficient for keywords similarity," in Lecture Notes in Engineering and Computer Science, 2013, vol. 2202.

[27] H. T. Huynh, N. Duong-Trung, D. Q. Truong, and H. X. Huynh, "Vietnamese text classification with textrank and jaccard similarity coefficient," Adv. Sci. Technol. Eng. Syst., vol. 5, no. 6, 2020, doi: 10.25046/aj050644.

[28] A. Giełczyk, M. Choras, and R. Kozik, "Lightweight verification schema for image-based palmprint biometric systems," Mob. Inf. Syst., vol. 2019, 2019, doi: 10.1155/2019/2325891.

[29] S. Bag, S. K. Kumar, and M. K. Tiwari, "An efficient recommendation generation using relevant Jaccard similarity," Inf. Sci. (Ny)., vol. 483, 2019, doi: 10.1016/j.ins.2019.01.023.

[30] T. T. N. Le and T. V. X. Phuong, "Privacy Preserving Jaccard Similarity by Cloud-Assisted for Classification," Wirel. Pers. Commun., vol. 112, no. 3, 2020, doi: 10.1007/s11277-02007131-6.

[31] A. Hashemi Fath, F. Madanifar, and M. Abbasi, "Implementation of multilayer perceptron (MLP) and radial basis function (RBF) neural networks to predict solution gas-oil ratio of crude oil systems," Petroleum, vol. 6, no. 1, 2020, doi: 10.1016/j.petlm.2018.12.002.

[32] C. K. Dewa, A. L. Fadhilah, and A. Afiahayati, "Convolutional Neural Networks for Handwritten Javanese Character Recognition," IJCCS (Indonesian J. Comput. Cybern. Syst., 2018, doi: 10.22146/ijccs.31144. 